\title{
Women Working In Fisheries At Ibrahim Hydri, Rehri Goth And Arkanabad
}

\author{
Nasreen Aslam Shah \\ Women's Studies \& Department of Social Work \\ University of Karachi
}

\begin{abstract}
This article emerges out of my study on fisheries at Ibrahim Hydri, Rehri Goth \& Arkanabad, a project assigned by Women Development Department, Government of Sindh. The overall objective of this study is to seek out information regarding the following issues: the status of women in family and community, type of work they are doing, reason of doing work and their system and mode of payment, overall their hygiene and health conditions of the women folk. Both qualitative and quantitative research methodologies were adopted for this study through which the researcher has analyzed different factors and circumstances which these women are experiencing. This study has, therefore, been conducted to explore the factual data about the women working in fisheries at Ibrahim Hydri, Rehri Goth and Arkanabad.
\end{abstract}

Keywords: Fisherwomen, Health Issues, Working Conditions, Socio-Economic Status, Physical and Mental Ailment.

$$
\begin{aligned}
& \text { تثخص }
\end{aligned}
$$

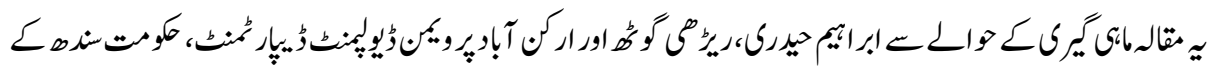

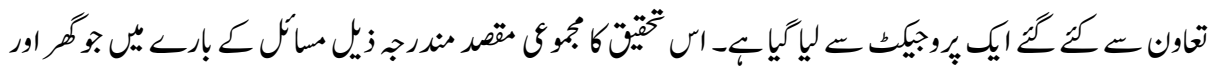

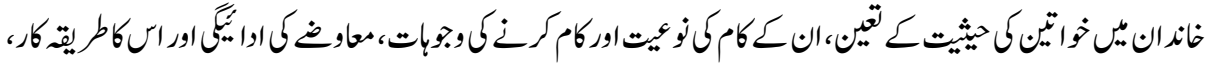

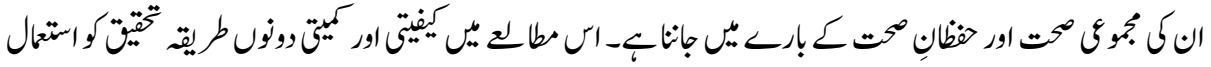

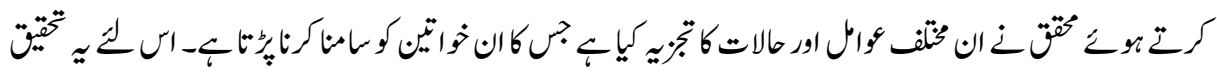

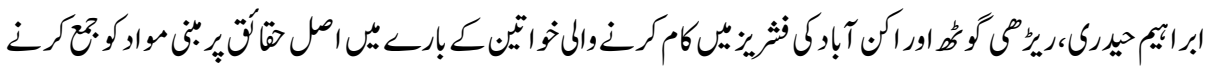

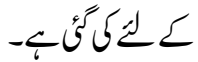

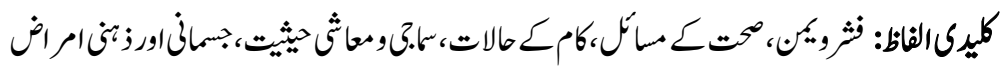

\section{Introduction}

Fisheries play a significant role in the growth of national income. This sector directly provides employment to 300,000 fishermen and in addition to this another 400,000 people 
are employed in ancillary industries. Pakistan is gifted with rich fishery potential and it is a major source of earning foreign exchange for the country. There are 16,000 fishing boats which operates fishing trips in shallow coastal waters of Pakistan as wee as in offshore regions lasting for few hours to about 25 days depending upon type of fishing. Total production which comes from inland and marine waters is roughly around 0.06 M.tons (Khan, 2016). Sindh province has been bestowed with natural fisheries resources on the marine side, almost $350 \mathrm{Km}$ coastal belt of Sindh is lying virtually untapped, which needs to be exploited for shrimp, crab, oyster, pearl culture etc. in enclosure, pen and ponds. Almost 300,000 hectors area is available in the deltaic area for this purpose. It is being observed that fresh water resources are being depleting fast in the Province of Sindh and Sea intrusion due to ecological changes. 72 Dehs (hamlets) out of 698 Dehs of Thatta and Badin Districts have completely eroded by the Sea. As the main thrust of our fisheries export is based on capture fisheries, which is being depleting day by day, hence aquaculture on marine and brackish water side is the only option to subsidize it, through cage, pens and pond culture techniques. In the fisheries sector of Pakistan the Province of Sindh holds the premier position by commanding $65 \%$ of fresh water, $100 \%$ of brackish and $71 \%$ of marine water resources of the total fisheries resources of Pakistan. These resources have commercially important about 400 varieties of marine, 200 different types of fish and 13 different varieties of shrimp (Government of Sindh, 2015). An exclusive economic zone (EEZ) of Pakistan has grown up by 150 nautical miles (200 nautical miles to 350 nautical miles) with the addition of 50,000 square kilometers of international waters to its seabed territory which allowing Pakistan to benefit from the natural resources contained in it (Sajjad, 2015). According to a statement issued by the Pakistan Navy that United Nations Commission on Limits of Continental Shelf has accepted Pakistan's claim for extension of its continental sea limits "This adds $50,000 \mathrm{sq} \mathrm{Kms}$ of continental shelf to the existing 240,000 sq Kms of EEZ under Pakistan's jurisdiction”. Pakistan is now fully enjoying its right over the resources of seabed and subsoil and also allowing it to drill for petroleum or lay submarine cables or pipelines in the added territory. This remarkable milestone in the history of Pakistan would bring immense economic benefits through the exploitation of comprehensive natural resources (The Express Tribune, March 21 ${ }^{\text {st }}, 2015$ ).

\section{Literature Review}

In economic system of Pakistan Fisheries and fishing industry has vital role. It also provides employment opportunities to people who live in coastal areas. Marine and Inland sources are in abundance in Pakistan. Makran coast (Balochistan) and the coast of Karachi (Sindh) are true distinct grounds for Marine fishing in Pakistan. Karachi is more important port therefore; government has taken steps to develop it as a fishing centre (Fishing Industry in Pakistan).

In Pakistan Fishing and fishing industry plays key role in serving humans as source of protein and increasing foreign exchange for the country as well. It also shares in GDP 
growth showing different statistics i.e. 0.3 percent in 2012 (Siddiqui, 2012) and 0.43 percent during the year 2014-2015. Government of Pakistan is now genuinely taking some measures for the improvement of fishing sector by focusing on introducing new strategies, developing value added products, increasing per capita fish consumption, improving social and economic conditions of fishing community (Government of Pakistan, 2014-2015) and along with that providing employment opportunity to these communities almost up to 1.5 million people. In rural areas of Sindh and Balochistan alternate employments do not exist, therefore, fishing is the best source of income generation and is also a way of improving standard of living. Fishing industry in such areas is a way of fulfilling negative gap between the demand and supply of fish (Siddiqui, 2012).

Catching fish is almost a male domain (Saigol, 2011); especially in deep sea waters it has high occupational risks. Whereas, women are engaged in household chores and other activities like preparing meals, mending nets, and women help their male counter parts in various activities, but their efforts remain unacknowledged. They are overburdened in all communities in both productive and reproductive roles (Institute for Community Organization Research, 2011). In small scale and fishing industry women's prominent role is in post-harvest, along with that in processing and marketing as well (Nishchith, 2000). As per international statistics women especially young women are engaged in fishing industry i.e. $80 \%$ women are engaged in marketing. $90 \%$ of the women workers are engaged in seafood processing firms in Sri Lanka (Central Bank of Sri Lanka, 2003). $60 \%$ in India and $80 \%$ workforce in Vietnam consist of female workers. In Bangladesh $60 \%$ women contribute in fishing industry and many of them are entrepreneurs. Gender discrimination stems out of the social setup thus keeping these women invisible. They have limited access to loan facilities, technology and capacity building. Various trends are seen as per circumstances e.g. When facilities of preservation and processing are provided then men starts competing women. On the other hand women are less paid as compared to men. These income generating activities and long working hours makes it difficult for women to fulfill their household responsibilities (FAO, 2016).

In fishing sector millions of women are involved in both formal and informal sector and paid and unpaid work. Women are usually engaged in work before and after fish catch, but they can also be seen in catching and harvesting. These women work at artisanal and industrial stage both. At artisanal stage they prepare and mend fishing nets, pots and baskets, hooks (used for baiting) and they even provide their services to the fishing boats whereas, at industrial level they perform post harvest tasks along with processing and marketing. Women work at fish harbours, they sort, and clean, dry, and smoke fish for marketing (Competitiveness Support Fund and Agriculture) while working at harbor women get a chance to keep substandard fish for their family. Though all these tasks which women perform are not that much easy because they have to make sure that during the process of sorting, cleaning and packing the nutritional value of the seafood should 
not be lost as consumer prefer to eat fish with full nutrient value. Therefore, it is needed to recognize efforts of women labour force in order to acknowledge their hard work (World Bank, 2010). In fisheries sector labour force mostly comprises of women e.g. in Western Africa and in Asia $80 \%$ of the seafood is prepared, sorted and cleaned by women for marketing (Focus). It is an established fact that women play important role in fish industry, but still actual facts and figures are not available to show women's involvement in fisheries sector. Women's work is of diverse nature but remain invisible.

As per recent studies in nine major sea food producing countries almost $46 \%$ women are playing a vital role in small scale fisheries. Some other international researches have also exposed that in third world countries women's economic participation is not highlighted in contrast to men. Women's role in fishery business is internationally kept hidden even though without women's participation men cannot do fishery business on their own. Women are very supportive in numerous ways and help their male counter parts but they get hardly anything from the profit amount (World Fish Cenre,2011).

Feminist perspective regarding fisher women is based on the fact that these women are multitasker and perform productive and reproductive roles at a time and doing almost all the household chores in their homes (Swanrangsi, 2003). Feminists raise a question that idea of production should be referred as production of goods as well as production of life. But production of life is not given much of a importance because it is considered as a natural phenomena. Therefore, private life is ignored and no improvement is made in this regard. In order to maintain gender based and equitable working environment in fisheries it is necessary to value and respect relationship between poor and rich, men and women whereas, race and nationality must not be a criteria to benefit the community. Feminist perspective also looks forward to redesign social values to reduce gender gap and it is focused to change the mind set which is the main cause of dominant discourse. Gender issues does not mean solving women issues, but to focus on gender balanced society and to address the roles, responsibilities, ethnicity, age, sex and marital status (ICFJ).

Recognizing this lack of interest in fisher women's lives and their struggle in life, in 1995, Researcher began to explore the veiled life of invisible fisherwomen. This exercise resulted in a small study entitled, Socio-Economic Study of Women in Fishermen's Village (Ayub, 1995). The site selected for this small study was Ibrahim Hyderi village, the oldest fishermen's settlement in Pakistan and known in local traditions as 'Machi Miani' (a place where fish are found). This study was conducted with the help of random sample of fifty women of fishermen families living in this village. The data was collected through face-to-face interviews of the respondents. Surprisingly, the profile of fisher women in the study conducted in 1995 and the study conducted in 2012, after an interval of seventeen years, is not different in many ways. The similarities in the life patterns of these two sets of women set apart in terms of years, make one imagine as if time stopped for them at some stage and they were fossilized to the extent that changes occurring in 
Karachi by-passed them completely. Fisherwomen of the 1995 study lived a life full of struggle to feed their families one good meal a-day. Living in semi-katcha houses or that ched-roofed quarter, majority of women along with their children fetched water every day on a routine basis. Women collected fuel wood for their kitchen. Children had no or little schooling; majority dropped-out after a few years. Health-care facilities were few. Women were found engaged in small-scale earning enterprises in addition to helping their men in the fishing (Shah, 1997). It is interesting to note that despite the time difference of more than a decade in the above-mentioned research studies, the pitiable working, and living conditions of women of the area has not improved. Indeed, as this study conducted in July 2012 shows, it has worsened the situation in the context of much flaunted development schemes and gender equity claims. This study was undertaken to examine how gender based division of labour in the fishing sector thwarts women's onward movement and keeps them in an inferior status.

Basic details and data about fisher women in Pakistan is very limited, and this trend is commonly seen globally. Women in all walks of life are ignored and neglected, thus, leaving women to face hardships as a result of this negligence and gender discrimination.

Taura \& Passfield (2011) identified that Solomon, Marshall and Tonga islands in 2011 have the same working conditions for fisher women as Pakistan. They both further elaborated that women are neglected because fishing industry is considered as men's domain (Tuara, 2011(a)). According to them gender stereotyping concepts that women are physically weak hinders in considering them as suitable for fishing industry (Tuara, 2011 (b)).

\section{Methodology}

To collect primary data for this research the team consisting of six members, including the researcher, made twelve field visits. A total of 309 women respondents were interviewed. A pre-constructed and pre-tested interviewing schedule was implemented to collect the required data to all of them by the pre-trained research team under the supervision of the researcher. Researcher read out the questions to each respondent and in case of any difficulty in understanding the nature of the question, researcher explained the content and the intent as simply as possible. Thus, each questionnaire was completed in at least an hour and a half. Both qualitative and quantitative research methodologies were adopted for this study. The sample for this study has been drawn on the basis of the snowball method. To achieve a better understanding of the situation faced by the women in the fisheries sector, this research undertook a survey which provided an opportunity to open an intensive dialogue with 309 women working in this sector in the selected areas.

\section{Key Findings of the Research}

We present our findings based on our field notes and observations and data collected by implementing questionnaire to our respondents. During our visits to the coastal villages 
of Ibrahim Hyderi, Rehri Goth, and Arkanabad, we saw that most of the residents were living below the poverty line and were deprived of basic human needs such as drinking water, quality education, and primary health.

We found groups of females, from little girls to aged and aging women (Table-1), reflects that high percentage of working women belongs to the age of more than forty years who are mostly illiterate and those who are literate were also not highly qualified (Table-2). The presence of 194 illiterate women, amounting to $62 \%$ is a number making government claim of even the poor rate of $35 \%$ female literacy rate skeptical. While asking about their marital status we come to know that majority of the respondents were married (Table-3). All of them are poor and they are earning not only for their personal needs but to support their families and to resolve their economic problems (Table-5). According to different researches women involved in other economic activities (other than fisheries community) have better chances to get education and learn different skills even they have better working conditions and salaries as compared to fisheries sector( World Health Statistics, 2010).

We found that they were working under harsh physical conditions; they are not satisfied with the hygiene conditions at work place (Table-8). Women face severe health issues while cleaning shrimps, because they are working in hazardous conditions, and they are not provided any kind of working kit to protect them. We also found women working with bare hands, which damages their skin and constant sitting with uncomfortable posture affects their physical and mental health and complaining severe backache problem, some of them suffer from muscular stress, mental tension, cervical spondylosis problem and reported that their eye sight also affected due to their work (Table-10 \& 11). Majority of them replied that their health conditions were better before starting their work and their health is deteriorating after they started work (Table-9). They told us that due to the absence of washrooms and toilets, they have to rush to their homes whenever they have a call of nature.

While asking about the type of work they are doing some of our respondents replied that $77.99 \%$ were engaged in shrimp pealing and cleaning, $6.80 \%$ were making fishing nets, $4.21 \%$ were involved in packing fish in boxes, $2.27 \%$ were making chatai (rugs) and $1.62 \%$ were engaged in taking out scallop from seashells while some other respondents who were involved in doing different typologies of work replied that they were doing work on adda, karchobi work, ralli making, embroidery, stitching, preparing pickle, making flowers, and weaving carpets.

The most important finding of this research is the story of 32 years old woman who accompanies her male family members on fishing trips, who helps them in catching fish and preparing meals for them on the boat. According to the typology of work out of 309 respondents only one woman goes with their male family members to catch fish in deep sea. Thus, portraying the picture of our society where women are not allowed to accompany men in their work, as women have restricted economic activities (Table-4). 
Women in the fisheries are extremely marginalized and exploited due to prevalent norms of gender segregation and their share and contributions remain limited (World Fish Centre, 2010) and were also engaged in the lowest paying jobs. They worked for long working hours and were also not permanently employed, a fact that had adverse effect on their earnings (Siddiqui, 2003). As $80.91 \%$ of the respondents said that the wages were paid by weighing the processed fish in kilograms and majority of them $(76.37 \%)$ were getting their wages on weekly basis whereas, some were getting on completion of consignment and on monthly basis (Table-6 \& 7).

Women are an integral part of a community; their status and roles are created, conceived and sustained by the community in which they live. Thus, for this study, Socio-Economic, Political, and Environmental Conditions of Women in Fisheries, awareness and knowledge about the society in which these women live and work, is a pre-requisite. Such knowledge is essential as both the statistical and narrative profile of a community provides the first step for planning future development schemes by identifying areas lacking in basic amenities. In addition, it assists in monitoring schemes and projects already under-way, and is the best tool for the appraisal and assessment of government policies and NGO interventions in the area.

In the coastal villages, fisher folk live an impoverished life; their living areas are the poorest and are marked by the absence of infrastructure and social services (World Bank, April, 2005). Un-kept dirt roads, clusters of shanties, some houses with semi-katcha structures, bunches of children who should be at school running around, toddlers following their mothers with water-pitchers or bundles of firewood on their heads, and young men, who should be at work, loitering around is the usual everyday site of this area. Even a casual conversation with a member of this community soon turns into a tale of misery. Poverty of the worst is the hallmark of the community. To relieve the situation and to eradicate their financial woes, they borrow loans that last forever; entangling them as tightly perhaps as the fish they catch is in their mesh.

\section{Conclusions}

This study, based on its findings, concludes how deep rooted gender imbalance is within the world of fisher folk, despite the immense crucial role that women play in sustaining fish industry. Women working in the warrahs earn low wages that are settled at 'piece rate' or on completion of a unit of work. This system makes women do more work in order to earn more. Long hours of work putting hands in buckets of ice-cold water leads to a variety of ailments, such as headache, muscle pain, and skin rashes.

One significant conclusion arising out of this study is related more to the future of the community and less to its present neglected state. The dismal state of lack of schooling, of the number of more out-of-school children than the number of children at school, and complete lack of health care and proper medication of children presents a bleak hope for 
the future. The findings need no explanation as it stands as testimony to the false claims of development and urbanization in Karachi.

The long toiling hours spend by mothers at peeling the shrimps kept in icy-cold water results in providing at best a one-time a-day meal to their children. We conclude this report by raising a question. Daughters of fisher women of today are the women of the next generation of the fishermen villages. Even a casual glance shows what would be the future of these little girls. Would the children of these hard-working mothers remain trapped in the same vicious circle of poverty and deprivation that is cast around their mothers? If no, then what is the way to move out?

\section{Recommendations}

1. First recommendation of the study is to urge that there is an urgent need to constitute a high level in inter-ministerial committee to develop and then implement short and long-term strategies to protect lives and resources of the country and to rescue women from the harsh life they are exposed today because of negligence and rickety policies.

2. This Commission should consist, among others social scientists, and researchers from centres of higher learning (universities) to generate more updated data on fisher women

3. Women Development Ministry should create a wider and in-depth sustainable gender sensitive development research for fisher women in all the fishing villages in order to prepare a holistic picture.

4. Formulation of a sustainable fishing policy with focus on ecosystem and its implementation, implementation of Labour Laws in fish warrahs. All the warrahs should be periodically monitored to check the implementation of these Labour Laws.

5. Micro-credit schemes for the fisher folk women should be started in consultation with First Women Bank

6. Skill-training and income-generating training centres for women of the fisherfolk community should be established by the Women Development Ministry.

7. Women of the area should be treated as equal partners in development.

\section{References}

Ayub, Nasreen (1995). Socio-Economic Study of Women in Fishermen's Village (1995). funded by the Research Facility Centre, University of Karachi (unpublished).

Central Bank of Sri Lanka (2003). Annual Report, Central Bank of Srilanka, Colombo, Sri Lanka, pp. 97-155. 
Competitiveness Support Fund (Pakistan), USAID/Pakistan (2009). Action Plan for Quality and Value Adding at Karachi Fisheries Harbour.

FAO. (2016). The State of World Fisheries and Aquaculture.

Fishing Industry in Pakistan -at: http://www.pakistanfishing.com/fishing-info/fishingindustry-in-pakistan

Focus : Fisheries and Food Security at: http://www.fao.org/focus/e/fisheries/women.htm

Government of Pakistan (2014-15). Pakistan Economic Survey, Ministry of Finance, Government of Pakistan.

Government of Sindh (2015). Livestock \& Fisheries Department, Government of Sindh Report.

ICSF. (2016). Gender Relations in Fisheries in Women in Fisheries, http://wif.icsf.net/index.php

Institute for Community Organization Research (2011). Nutritional and Health Status of Fishing Communities in the Uttan-Gorai Area with Special Emphasis on Women, Mumbai, India, Institute for Community Organization Research, p.15.

Khan, Prof. Hasan (Aug. 23, 2016) Fisheries Management, Policy and Implementation: A Review. at: http://www.pakissan.com/english/allabout/fisheries/fisheries management.shtml

Nishchith, V.D. (2000). Role and Status of Women Employed in Seafood Processing Units In India, No.112/1c, $7^{\text {th }}$ Cross, J.P.Nagar,ii Phase, India, Banglore, pp.127-135.

Saigol, Rubina (January 2011). Women's Empowerment in Pakistan: A Scoping Study by the Gender Equity Program (GEP), Aurat Foundation, p.11.

Sajjad, Syed Baqir (March 21, 2015). Pakistan Seabed Territory Grows by 50,000 square Kilometers, Published in Dawn.

Shah, Nasreen Aslam (1997). Women in Fisher (Wo)Men's Village in Pakistan Journal of Women's Studies: Alam-e-Niswan, vol.4:1, pp.63-73.

Siddiqui, Prof. Saeed Ahmed. (March 12-18, 2012). Fishing \& Fisheries Industry in Pakistan, Economist at: http://www.pakistaneconomist.com/pagesearch/SearchEngine2012/ S.E190.php 
Siddiqui, Rehana, Shahnaz Hamid, Rehana Siddiqui (2003). 'Gender and Adjustment Policies: Evidence from Pakistan' Chapter 6 in Tracking Gender Equity under Economic Reforms: Continuity in South Asia, Swapna Mukhopadhyay \& Ratna Sudarshan, (editors), International Research Centre, New Delhi, pp.153-195.

Swanrangsi, S. (2003). Technological Changes and their Implications for Women in Fisheries, Fish Inspection and Quality Control Division, Department of Fisheries, Bangkok, Thailand, pp.35-41.

The Express Tribune (March 21 $1^{\text {st }}$, 2015). Territorial Waters: Pakistan's Sea Grows by 50,000 sq kms. at: http://tribune.com.pk/story/856716/territorial-waters-pakistanssea-grows-by-50000-sq-kms/

Tuara, Patricia and Kelvin Passfield. 2011(a). Gender in Oceanic and Coastal Fisheries and Management, Based on Case studies in Solomon Islands, Marshall Islands and Tonga, p.3 www.spc.int/DigitalLibrary/Doc/.../Tuara 11_GenderOceania.pdf

Tuara, Patricia and Kelvin Passfield. 2011(b). 'Issues on gender in Oceanic and coastal fisheries science and management in the Pacific Islands. Case studies from Solomon Islands, Marshall Islands, and Tonga Islands' in Fisheries, No. 22, July 2012, pp. 2-16. www.spc.int/DigitalLibrary/Doc/FAME/InfoBull/.../22/ WIF22.pdf

World Bank (April 25, 2005). Socioeconomic Study and Proposal For Livelihood Improvements: Badin and Thatta District, Sindh, Pakistan, Agricultural and Rural Development Sector Unit South Asia Region, Document of the World Bank

World Bank., Food and Agriculture Organization and World Fish Centre (2010). The Hidden Harvests - The Global Contribution of Capture Fisheries, Conference Edition, Washington DC.

World Fish Centre (2010). Gender and Fisheries: Do Women Support, Complement or Subsidized Men's Small-Scale Fishing Activities?, Issue Brief 2108, Penang, Malaysia, World Fish Centre, p.8.

World Fish Centre (2011). Gender and Aquaculture: Sharing the Benefits Equitably (Issues Brief \2011-32), World Fish Centre.

World Health Statistics (2010). Health and Hygiene Conditions, Available at, http//:herproject.org/downloads/countryresources/her_health_needs_bangladesh,pdf. 


\section{Annex- Table of the Study Findings}

Table - 1

Distribution of respondents according to their age groups

\begin{tabular}{|l|c|c|}
\hline Age in Years & Frequency & Percentage \\
\hline $5-9$ Years & 12 & $3.88 \%$ \\
\hline $10-14$ Years & 32 & $10.36 \%$ \\
\hline $15-19$ Years & 39 & $12.62 \%$ \\
\hline $20-24$ Years & 31 & $10.03 \%$ \\
\hline $25-29$ Years & 32 & $10.35 \%$ \\
\hline $30-34$ Years & 31 & $10.03 \%$ \\
\hline $35-39$ Years & 28 & $9.06 \%$ \\
\hline More than 40 Years & 104 & $33.66 \%$ \\
\hline Total & $\mathbf{3 0 9}$ & $\mathbf{1 0 0 \%}$ \\
\hline
\end{tabular}

Table -2

Distribution of respondents according to their educational status

\begin{tabular}{|l|c|c|}
\hline Educational Status & Frequency & Percentage \\
\hline Illiterate & 194 & $62.78 \%$ \\
\hline Literate & 52 & $16.83 \%$ \\
\hline Nazrah Quran & 37 & $11.97 \%$ \\
\hline Primary & 20 & $6.47 \%$ \\
\hline Middle & 03 & $0.97 \%$ \\
\hline Matric & 03 & $0.97 \%$ \\
\hline Total & $\mathbf{3 0 9}$ & $\mathbf{1 0 0 \%}$ \\
\hline
\end{tabular}

Table -3

Distribution of respondents according to their marital status

\begin{tabular}{|l|c|c|}
\hline Marital Status & Frequency & Percentage \\
\hline Un-Married & 97 & $31.39 \%$ \\
\hline Married & 199 & $64.40 \%$ \\
\hline Divorced & 08 & $2.59 \%$ \\
\hline Widowed & 05 & $1.62 \%$ \\
\hline Total & $\mathbf{3 0 9}$ & $\mathbf{1 0 0 \%}$ \\
\hline
\end{tabular}


Table -4

Distribution of the respondents according to the type of work

\begin{tabular}{|l|c|c|}
\hline Type of Work & Frequency & Percentage \\
\hline Shrimps Pealing \& Cleaning & 241 & $77.99 \%$ \\
\hline Carpet Weaving & 01 & $0.32 \%$ \\
\hline Cropping & 01 & $0.32 \%$ \\
\hline Ralli Making & 01 & $0.32 \%$ \\
\hline Making Flowers with Fabric & 02 & $0.65 \%$ \\
\hline Packing Fish in Cartons & 13 & $4.21 \%$ \\
\hline Karchobi & 03 & $0.97 \%$ \\
\hline Stitching Women's Dresses & 03 & $0.97 \%$ \\
\hline Net Making & 21 & $6.80 \%$ \\
\hline Taking out Scallop from Seashells & 05 & $1.62 \%$ \\
\hline Embroidery on Sindhi Suits & 03 & $0.97 \%$ \\
\hline Pickle Making & 02 & $0.65 \%$ \\
\hline Khokha (Tuck Shop) & 04 & $1.29 \%$ \\
\hline Chatai (Rug) Making & 07 & $2.27 \%$ \\
\hline Work on Adda & 01 & $0.32 \%$ \\
\hline Going on Boats for Hunting Fish & 01 & $0.32 \%$ \\
\hline Total & $\mathbf{3 0 9}$ & $\mathbf{1 0 0 \%}$ \\
\hline
\end{tabular}

Table -5

Distribution of respondents according to the reasons of doing work

\begin{tabular}{|l|c|c|}
\hline Reasons of Doing Work & Frequency & Percentage \\
\hline Poverty & 150 & $48.54 \%$ \\
\hline Needs of Family & 79 & $25.57 \%$ \\
\hline Economic Problems & 76 & $24.50 \%$ \\
\hline Personal Needs & 4 & $1.29 \%$ \\
\hline Total & $\mathbf{3 0 9}$ & $\mathbf{1 0 0 \%}$ \\
\hline
\end{tabular}

Table -6

Distribution of respondents according to the system of payment

\begin{tabular}{|l|c|c|}
\hline System of Payment & Frequency & Percentage \\
\hline Per Kilo Gram $(\mathrm{Kg})$ & 250 & $80.91 \%$ \\
\hline Per Dozen & 14 & $4.53 \%$ \\
\hline Per Piece & 20 & $6.47 \%$ \\
\hline Per Size of the Length of the Product & 21 & $6.80 \%$ \\
\hline Own Shop & 4 & $1.29 \%$ \\
\hline Total & $\mathbf{3 0 9}$ & $\mathbf{1 0 0 \%}$ \\
\hline
\end{tabular}


Table -7

Distribution of respondents according to the mode of payment

\begin{tabular}{|l|c|c|}
\hline Mode of Payment & Frequency & Percentage \\
\hline Weekly & 236 & $76.37 \%$ \\
\hline 15 Days & 05 & $1.62 \%$ \\
\hline Monthly & 13 & $4.21 \%$ \\
\hline $\begin{array}{l}\text { On completion of Production / } \\
\text { Consignment }\end{array}$ & 55 & $17.80 \%$ \\
\hline Total & $\mathbf{3 0 9}$ & $\mathbf{1 0 0 \%}$ \\
\hline
\end{tabular}

Table -8

Distribution of respondents according to what are the hygiene conditions over here

\begin{tabular}{|l|c|c|}
\hline $\begin{array}{l}\text { What are the Hygienic Conditions Over } \\
\text { Here }\end{array}$ & Frequency & Percentage \\
\hline Satisfactory & 26 & $8.41 \%$ \\
\hline Not Satisfactory & 228 & $73.79 \%$ \\
\hline Domestic Work & 55 & $17.80 \%$ \\
\hline Total & $\mathbf{3 0 9}$ & $\mathbf{1 0 0 \%}$ \\
\hline
\end{tabular}

Table -9

Distribution of respondents according to are they healthier now or before

\begin{tabular}{|l|c|c|}
\hline Healthier Now or Before & Frequency & Percentage \\
\hline Healthier Before & 203 & $65.69 \%$ \\
\hline Not Healthier Now & 51 & $16.50 \%$ \\
\hline Still Healthy & 55 & $17.79 \%$ \\
\hline Total & $\mathbf{3 0 9}$ & $\mathbf{1 0 0 \%}$ \\
\hline
\end{tabular}

Table -10

Distribution of respondents according to facing any physical and mental ailment due to work

\begin{tabular}{|l|c|c|}
\hline $\begin{array}{l}\text { Facing any Physical and } \\
\text { Mental Ailment Due to } \\
\text { Work }\end{array}$ & Frequency & Percentage \\
\hline Yes & 284 & $91.91 \%$ \\
\hline No & 25 & $8.09 \%$ \\
\hline Total & $\mathbf{3 0 9}$ & $\mathbf{1 0 0 \%}$ \\
\hline
\end{tabular}




\section{Table -11}

Distribution of respondents according to if yes, then what type of affect

\begin{tabular}{|l|c|c|}
\hline If Yes then What Type of Affect & Frequency & Percentage \\
\hline Eye Sight Affected & 13 & $4.58 \%$ \\
\hline Cervical Spondylosis Problem & 07 & $2.46 \%$ \\
\hline Mental Tension & 12 & $4.23 \%$ \\
\hline Muscular Stress & 74 & $26.06 \%$ \\
\hline Backache & 155 & $54.58 \%$ \\
\hline No Change Occurs & 23 & $8.10 \%$ \\
\hline Total & $\mathbf{2 8 4}$ & $\mathbf{1 0 0 \%}$ \\
\hline
\end{tabular}

Dr. Nasreen Aslam Shah is Meritorious Professor \& Chairperson in the Department of Social Work and Director, Centre of Excellence for Women's Studies, University of Karachi. 